\title{
Human antimicrobial peptides' antifungal activity against Aspergillus fumigatus
}

\author{
A. Lupetti - J. T. van Dissel • C. P. J. M. Brouwer • \\ P. H. Nibbering
}

Received: 18 January 2008 / Accepted: 12 May 2008 / Published online: 20 June 2008

(C) The Author(s) 2008

\begin{abstract}
In light of the need for new antifungals, we compared the in vitro antifungal activity of two peptides derived from human lactoferrin (hLF), i.e., $h L F(1-11)$ and $\mathrm{hLF}(21-31)$, two analogs of histatin 5, further referred to as dhvar4 and dhvar5, and two ubiquicidin (UBI)-derived peptides, i.e., UBI 18-35 and UBI 29-41, with that of amphotericin B against Aspergillus fumigatus hyphae using the MTT assay. The results revealed a dose-dependent antifungal activity for all peptides, with dhvar5 being the most potent peptide. In addition, $\mathrm{hLF}(1-11)$, dhvar5, and UBI 18-35 were effective against $A$. fumigatus conidia. Furthermore, $\mathrm{hLF}(1-11)$ did not lyze human erythrocytes, whereas dhvar5 $(\geq 16 \mu \mathrm{M})$ and UBI 18-35 $(\geq 20 \mu \mathrm{M})$ were hemolytic. Based on these in vitro results and their effectiveness against infections in mice, we concluded that $\mathrm{hLF}(1-11)$ and dhvar5 are promising candidates for the development of new agents against $A$. fumigatus infections.
\end{abstract}

\footnotetext{
A. Lupetti $\cdot$ J. T. van Dissel $\cdot$ P. H. Nibbering

Department of Infectious Diseases,

Leiden University Medical Center,

P.O. Box 9600, 2300 Leiden, The Netherlands
}

\author{
A. Lupetti $(\bowtie)$ \\ Dipartimento di Patologia Sperimentale, Biotecnologie Mediche, \\ Infettivologia ed Epidemiologia, \\ Sezione di Microbiologia e Virologia, Università di Pisa, \\ Via S. Zeno 37-39, \\ Pisa 56127, Italy \\ e-mail: alupetti@biomed.unipi.it \\ C. P. J. M. Brouwer \\ AM-Pharma BV, \\ Bunnik, The Netherlands
}

\section{Introduction}

A large surveillance in the United States from 1980 through 1997 revealed that, of the deaths in which an infectious disease was the underlying cause, the mortality due to invasive mycoses increased from the tenth most common cause in 1980 to the seventh most common in 1997, with an impressive 3.6-fold increase in mortality associated with aspergillosis [1]. Furthermore, a systematic review of the literature revealed a case-fatality rate of $58 \%$ for patients with invasive aspergillosis and was especially high in bone marrow transplant recipients (87\%) [2]. Moreover, amphotericin B deoxycholate and lipid formulations thereof failed to prevent death in one-half to two-thirds of these patients [2]. Despite the introduction of several new antifungals (newer generation azoles and echinocandins), the mortality and morbidity of aspergillosis is still high [2, 3].

The availability of effective strategies to improve the outcome for patients with opportunistic mycoses, in particular, invasive aspergillosis, constitutes an enormous medical need and antimicrobial peptides [4-6] may be promising candidates for this purpose because their mechanisms of action differ from that of current antifungals and the acquisition of resistant mutants is less likely to occur. An interesting approach is the use of synthetic peptides derived from natural antimicrobial proteins/peptides with antifungal activities. For example, human lactoferrin (hLF), which is a protein synthesized and released by activated neutrophils and mucosal epithelial cells, exerted antifungal activities. This antimicrobial protein contains two cationic domains in its $\mathrm{N}$ terminus. A recent study indicated that a synthetic peptide including the first cationic domain, further referred to as $\mathrm{hLF}(1-11)$, is more effective in killing Candida albicans than the native protein or a peptide, $h L F(21-31)$, comprising the second cationic domain [7]. 
Moreover, the $\mathrm{hLF}(1-11)$ peptide is effective against an invasive infection with fluconazole-resistant $C$. albicans in mice [6]. Histatin 5 is a histidine-rich, cationic peptide secreted by human parotid and submandibular glands [8]. From this peptide, several analogs with antifungal activities, further referred to as dhvar4 and dhvar5, have been designed [9]. Furthermore, our research has focused on ubiquicidin, a 6,648-Da linear cationic antimicrobial peptide produced by IFN- $\gamma$-activated murine macrophages and human airway epithelial cells [10]. This peptide displays antimicrobial activity against a variety of bacteria and $C$. albicans species. Recently, synthetic peptides derived from ubiquicidin, e.g., UBI 18-35, and UBI 29-41, have been selected on the basis of their antimicrobial activities [11]. In a first attempt to select the most promising candidates, we compared the in vitro antifungal activities of these six synthetic antimicrobial peptides against Aspergillus fumigatus and their hemolytic effects.

\section{Materials and methods}

Fungal strain and growth conditions

A. fumigatus (a clinical isolate) was cultured on potato dextrose agar for 4 days at $30^{\circ} \mathrm{C}$. A suspension of conidia was prepared by the filtration of this culture and washed twice in $10 \mathrm{mM}$ sodium phosphate buffer (NaPB; pH 7.4). In some experiments, the conidia were used as described. However, in most experiments, hyphae were studied. For this purpose, $5 \times 10^{4}$ colony-forming conidia $\mathrm{ml}^{-1}$ of yeast nitrogen base (YNB) medium supplemented with $2 \%$ glucose were cultured in flat-bottom 24-well plates for $15 \mathrm{~h}$ at $30^{\circ} \mathrm{C}$ until $>95 \%$ of the conidia had germinated.

\section{Antimicrobial peptides}

The synthetic peptides hLF(1-11) (GRRRRSVQWCA; Mw 1,374 Da), hLF(21-31) (FQWQRNMRKVR; Mw 1,567 Da), UBI 18-35 (KVAKQEKKKKKTGRAKRR; 2,169 Da), UBI 29-41 (TGRAKRRMQYNRR; 1,693 Da), and peptide 4 (part of gp120 from HIV-1; RPVVSTQLLLNGSLAEEEVV; 2,171 Da) were prepared and purified as described [7]. The peptides dhvar4 (KRLFKKLLFSLRKY; 1,841 Da) and dhvar5 (LLLFLLKKRKKRKY; 1,848 Da) were a kind gift from Dr. W. van't Hof (Academic Centre for Dentistry, Department of Oral Biochemistry, Free University, Amsterdam, the Netherlands). The purity of the various peptides ranged from $88-97 \%$, as determined by reverse-phase highperformance liquid chromatography (RP-HPLC). The peptides were stored and used as previously described [7].
Effects of peptides against $A$. fumigatus hyphae using the MTT assay

To quantitate the antifungal activities of antimicrobial peptides, adherent hyphae were washed twice in $\mathrm{NaPB}$ before exposure for $1 \mathrm{~h}$ at $37^{\circ} \mathrm{C}$ to the various peptides. Peptide 4 was used as the negative control and amphotericin B as the positive control. Next, hyphae were washed twice and the mass of viable A. fumigatus was quantitated by a rapid colorimetric assay [12] using the tetrazolium salt (3-[4,5-dimethylthiazol-2-yl]-2,5-diphenyltetrazolium bromide; MTT). Hyphal damage was calculated by comparing the absorption by peptide-treated organisms with that from untreated organisms using the following equation:

percentage of hyphal damage

$$
=\left[1-\frac{A_{\text {with peptide } / \text { amphotericin B }}}{A_{\text {without peptide/amphotericin B }}}\right] \times 100
$$

where $A$ is the absorbance at $570 \mathrm{~nm}$.

For comparison of the antifungal effects of the various antimicrobial peptides against $A$. fumigatus, we calculated the concentration of the peptides at which $50 \%$ of the maximal antifungal activity is reached by non-linear regression with the dose-effect model according to the following equation [13]:

$E=E_{\max } \times \frac{C}{E C_{50}+C}$

where $E$ is the observed antifungal effect at a given concentration $(C)$ of the peptide, $E_{\max }$ is the maximal antifungal activity, and $E C_{50}$ is the estimated concentration of the peptide at which $50 \%$ of the maximal antifungal activity is reached.

Effects of peptides against $A$. fumigatus conidia using the AlamarBlue ${ }^{\mathrm{TM}}$ assay

To compare the effects of peptides against A. fumigatus conidia, we determined their minimal inhibitory concentrations (MICs) as recommended by the National Committee for Clinical Laboratory Standards (NCCLS) using AlamarBlue $^{\mathrm{TM}}$ [14]. In short, $1 \mathrm{ml}$ of a suspension of approximately $1-2 \times 10^{3}$ conidia/ml of RPMI 1640 medium with L-glutamine was pipetted together with $25 \mu$ l of AlamarBlue ${ }^{\mathrm{TM}}$ into the wells of a 24-well plate and then the various antimicrobial peptides or, as the control, no peptide were added. After incubation for $72 \mathrm{~h}$ at $30^{\circ} \mathrm{C}$, the color change from dark blue to red was quantitated by measuring the absorbance at $600 \mathrm{~nm}$. The MIC was defined as the minimal concentration of the antimicrobial peptide preventing the development of the red color. 
Hemolysis assay

We used a hemolysis assay to establish the cytotoxicity of the different peptides. Briefly, freshly collected heparinized blood from healthy individuals was centrifuged at $100 \mathrm{~g}$ for $15 \mathrm{~min}$. The erythrocytes were washed three times with PBS, centrifuged at $1,000 \mathrm{~g}$ for $10 \mathrm{~min}$, and resuspended in PBS to a concentration of $1 \%(\mathrm{v} / \mathrm{v})$. Antimicrobial peptides were serially diluted in PBS (range 1.56-600 $\mu \mathrm{g} / \mathrm{ml}$ ) and $100 \mu \mathrm{l}$ thereof was added in triplicate to $100 \mu \mathrm{l}$ of the erythrocyte suspension. After incubation for $1 \mathrm{~h}$ at $37^{\circ} \mathrm{C}$, the mixtures were centrifuged at $1,000 \mathrm{~g}$ for $5 \mathrm{~min}$ and $150 \mu \mathrm{l}$ of the supernatants were transferred to a flat-bottom 96-well plate for measurement of the hemoglobin release by reading the absorbance at $450 \mathrm{~nm}$. PBS and 1\% Tween-20 were used to establish $0 \%$ and $100 \%$ hemolysis. The percentage of intact erythrocytes was calculated using the following formula:

$\left(1-\frac{A_{\text {peptide }}-A_{\mathrm{PBS}}}{A_{\text {Tween }}-A_{\mathrm{PBS}}}\right) \times 100 \%$

where $A_{\text {peptide }}$ is the absorbance at $450 \mathrm{~nm}$ in the well containing the peptide, $A_{\mathrm{PBS}}$ the absorbance at $450 \mathrm{~nm}$ in the well to which PBS was added, and $A_{\text {Tween }}$ is the absorbance at $450 \mathrm{~nm}$ in the well containing Tween-20.

\section{Statistical analyses}

Differences between the values for cells exposed to antimicrobial peptides and those exposed to peptide 4 were analyzed using the Mann-Whitney $U$-test. The level of significance was set at $p<0.05$.

\section{Results}

Antifungal activities of antimicrobial peptides

The results revealed a dose-dependent antifungal activity against $A$. fumigatus hyphae for $\mathrm{hLF}(1-11)\left(R^{2}=0.69\right.$; $p<0.05), \operatorname{hLF}(21-31) \quad\left(R^{2}=0.99 ; p<0.05\right)$, dhvar4 $\left(R^{2}=0.83 ; \quad p<0.05\right)$, dhvar5 $\left(R^{2}=0.87 ; p<0.05\right)$, UBI 18 $35\left(R^{2}=0.73 ; p<0.05\right)$, and UBI 29-41 $\left(R^{2}=0.95 ; p<0.05\right)$; the control peptide 4 being ineffective (Fig. 1). The maximum hyphal damage by the various antimicrobial peptides amounted to $70-80 \%$, which was similar to the values for $\geq 0.1 \mathrm{nM}$ amphotericin $\mathrm{B}$. Comparison of the $E C_{50}$ values for the various peptides revealed that dhvar5 $\left(E C_{50}=\right.$ $3 \pm 1 \mu \mathrm{M})$ is the most potent peptide; the $E C_{50}$ values for $\mathrm{hLF}$ (1-11), hLF(21-31), dhvar4, UBI 18-35, and UBI 29-41 being $29 \pm 5 \mu \mathrm{M}, 142 \pm 13 \mu \mathrm{M}, 19 \pm 5 \mu \mathrm{M}, 37 \pm 15 \mu \mathrm{M}$, and $91 \pm 19 \mu \mathrm{M}$, respectively. Notably, $\mathrm{hLF}(1-11)$ is 5-fold more effective than $\mathrm{hLF}(21-31)$, dhvar5 is 6-fold more potent than dhvar4, and UBI 18-35 is almost 3 -fold more effective than
UBI 29-41 in damaging A. fumigatus hyphae. In agreement, the MIC values for dhvar5, $\operatorname{hLF}(1-11)$, UBI 18-35, and amphotericin $\mathrm{B}$ against $A$. fumigatus conidia amounted to $3.6 \pm 2.2 \mu \mathrm{M}, 5 \pm 4 \mu \mathrm{M}, 18 \pm 13 \mu \mathrm{M}$, and $2.2 \pm 0.8 \mu \mathrm{g} / \mathrm{ml}$, respectively $(n=5-7)$.

Hemolytic activity of antimicrobial peptides

The peptides hLF(1-11) and UBI 29-41 did not lyze human erythrocytes at concentrations $\geq 200 \mu \mathrm{M}$, whereas dhvar5, $\mathrm{hLF}(21-31)$, and UBI 18-35 caused significant hemolysis

$(\mu \mathbf{M})$

\section{hLF(1-11)}
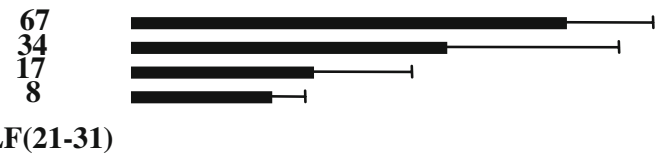

hLF(21-31)

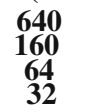

32

dhvar4
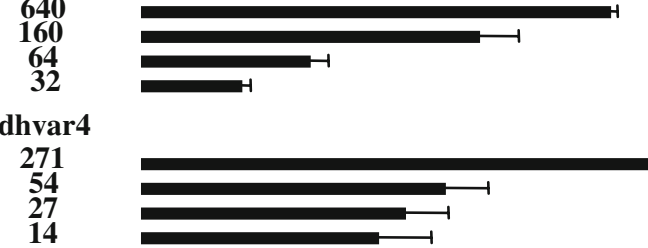

271
54
27
14

dhvar5

16
8
4
2

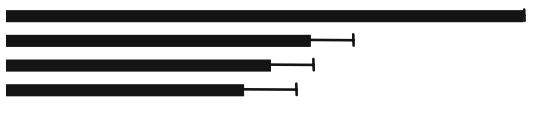

UBI 18-35

46

46
34
23
12

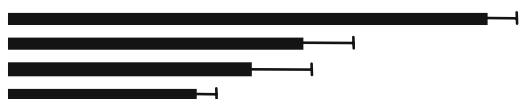

UBI 29-41

295

148

74
37

eptide 4

46 口-

no peptide 마

amphotericin B (nM)

10
0.1
0.01

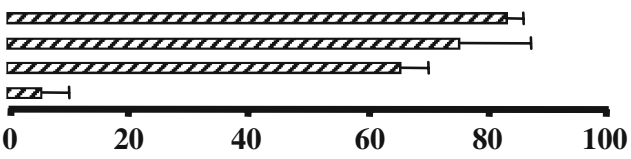

Hyphal damage (\%)

Fig. 1 Hyphal damage of Aspergillus fumigatus by hLF(1-11), hLF (21-31), dhvar4, dhvar5, UBI 18-35, UBI 29-41 peptides and amphotericin B. Aspergillus fumigatus hyphae were exposed to various concentrations of $\mathrm{hLF}(1-11), \operatorname{hLF}(21-31)$, dhvar4, dhvar5, UBI 18-35, and UBI 29-41 (solid bars), peptide 4 or no peptide (open bars; negative controls) or amphotericin B (hatched bars; positive control) for $1 \mathrm{~h}$. Next, the mass of viable A. fumigatus was quantitated by the MTT assay. Hyphal damage was calculated by comparing the absorbance at $570 \mathrm{~nm}$ by peptide-treated organisms with that by control organisms either untreated or treated with peptide 4. The results are shown as the means (plus standard deviation [SD]) of at least three independent experiments 
$(>2-3 \%$ ) at $\geq 16 \mu \mathrm{M}, \geq 16 \mu \mathrm{M}$, and $\geq 20 \mu \mathrm{M}$, respectively. The hemolytic activity of dhvar4 was not tested.

\section{Discussion}

The main conclusion from the present results is that $\mathrm{hLF}(1-$ 11) and dhvar5 are the most promising candidates for the development of new agents to treat infections with $A$. fumigatus. This conclusion is based on the following lines of evidence.

First, dhvar5 and hLF(1-11) were among the most potent peptides against $A$. fumigatus hyphae in vitro, and they were also active against $A$. fumigatus conidia in vitro. It should be realized that the antifungal activities of antimicrobial peptides in vitro may not reflect their antifungal activity in infected animals. For example, we reported that the doses of $\mathrm{hLF}(1-11)$ required for antifungal effects in mice with a disseminated C. albicans infection were much lower than that required in in vitro experiments [6]. Possible explanations for these observations include synergistic/additive effects between this peptide and hostderived antifungal factors, such as endogenous antimicrobial proteins/peptides and reactive oxygen intermediates [6]. Furthermore, the hLF(1-11) peptide, and perhaps dhvar5 as well, stimulates the antimicrobial activities of host cells, e.g., human mononuclear phagocytes [15]. Second, at the highest concentrations tested, no toxicity of hLF(1-11) and UBI 29-41 on human erythrocytes has been observed, while dhvar5 and hLF(21-31) caused significant hemolysis at a concentration $\geq 16 \mu \mathrm{M}$ and UBI $18-35$ at a concentration $\geq 20 \mu \mathrm{M}$. Moreover, safety studies with $\mathrm{hLF}(1-11)$ in laboratory animals and humans have been successfully completed. Thirdly, all peptides under investigation displayed antibacterial activities against infections with, e.g., methicillin-resistant Staphylococcus aureus (MRSA) in mice [11] and the $\mathrm{hLF}(1-11)$ peptide is effective against an invasive $C$. albicans infection in mice [6]. Since both $\mathrm{hLF}(1-11)$ and dhvar5 act synergistically in vitro with current antifungal agents against Candida species [9, 16], it may be expected that such combinations are also highly effective against infections with $A$. fumigatus. If effective in vivo, such combinations may reduce the dose and duration of anti-infective agents and the use of multiple antibiotics, thereby, limiting the emergence of drug-resistant strains.

Open Access This article is distributed under the terms of the Creative Commons Attribution Noncommercial License which permits any noncommercial use, distribution, and reproduction in any medium, provided the original author(s) and source are credited.

\section{References}

1. McNeil MM, Nash SL, Hajjeh RA, Phelan MA, Conn LA, Plikaytis BD, Warnock DW (2001) Trends in mortality due to invasive mycotic diseases in the United States, 1980-1997. Clin Infect Dis 33:641-647

2. Lin SJ, Schranz J, Teutsch SM (2001) Aspergillosis case-fatality rate: systematic review of the literature. Clin Infect Dis 32:358366

3. Herbrecht R, Denning DW, Patterson TF, Bennett JE, Greene RE, Oestmann JW, Kern WV, Marr KA, Ribaud P, Lortholary O, Sylvester R, Rubin RH, Wingard JR, Stark P, Durand C, Caillot D, Thiel E, Chandrasekar PH, Hodges MR, Schlamm HT, Troke PF, de Pauw B; Invasive Fungal Infections Group of the European Organisation for Research and Treatment of Cancer and the Global Aspergillus Study Group (2002) Voriconazole versus amphotericin B for primary therapy of invasive aspergillosis. N Engl J Med 347:408-415

4. Thevissen K, Kristensen HH, Thomma BP, Cammue BP, François IE (2007) Therapeutic potential of antifungal plant and insect defensins. Drug Discov Today 12:966-971

5. Zasloff M (2002) Antimicrobial peptides of multicellular organisms. Nature 415:389-395

6. Lupetti A, Brouwer CP, Bogaards SJ, Welling MM, de Heer E, Campa M, van Dissel JT, Friesen RH, Nibbering PH (2007) Human lactoferrin-derived peptide's antifungal activities against disseminated Candida albicans infection. J Infect Dis 196:14161424

7. Lupetti A, Paulusma-Annema A, Welling MM, Senesi S, van Dissel JT, Nibbering PH (2000) Candidacidal activities of human lactoferrin peptides derived from the $\mathrm{N}$ terminus. Antimicrob Agents Chemother 44:3257-3263

8. Oppenheim FG, Xu T, McMillian FM, Levitz SM, Diamond RD, Offner GD, Troxler RF (1988) Histatins, a novel family of histidine-rich proteins in human parotid secretion. Isolation, characterization, primary structure, and fungistatic effects on Candida albicans. J Biol Chem 263:7472-7477

9. Helmerhorst EJ, Reijnders IM, van't Hof W, Simoons-Smit I, Veerman EC, Amerongen AV (1999) Amphotericin B- and fluconazole-resistant Candida spp., Aspergillus fumigatus, and other newly emerging pathogenic fungi are susceptible to basic antifungal peptides. Antimicrob Agents Chemother 43:702704

10. Hiemstra PS, van den Barselaar MT, Roest M, Nibbering PH, van Furth R (1999) Ubiquicidin, a novel murine microbicidal protein present in the cytosolic fraction of macrophages. J Leukoc Biol 66:423-428

11. Brouwer CP, Bogaards SJ, Wulferink M, Velders MP, Welling MM (2006) Synthetic peptides derived from human antimicrobial peptide ubiquicidin accumulate at sites of infections and eradicate (multi-drug resistant) Staphylococcus aureus in mice. Peptides 27:2585-2591

12. Levitz SM, Diamond RD (1985) A rapid colorimetric assay of fungal viability with the tetrazolium salt MTT. J Infect Dis 152:938-945

13. Schippers EF, van't Veer C, van Voorden S, Martina CA, Huizinga TW, le Cessie S, van Dissel JT (2005) IL-10 and tolllike receptor-4 polymorphisms and the in vivo and ex vivo response to endotoxin. Cytokine 29:215-228 
14. Pfaller MA, Grant C, Morthland V, Rhine-Chalberg J (1994) Comparative evaluation of alternative methods for broth dilution susceptibility testing of fluconazole against Candida albicans. J Clin Microbiol 32:506-509

15. van der Does AM, Bogaards SJ, van Dissel JT, Nibbering PH (2007) The antimicrobial peptide hLF1-11 enhances recognition and elimination of pathogens by macrophages. In: Program and abstracts of the VIIth International Conference on Lactoferrin. Abstract no. O-VIII-6, 50

16. Lupetti A, Paulusma-Annema A, Welling MM, DogteromBallering H, Brouwer CP, Senesi S, van Dissel JT, Nibbering PH (2003) Synergistic activity of the N-terminal peptide of human lactoferrin and fluconazole against Candida species. Antimicrob Agents Chemother 47:262-267 